\title{
Does women's employment growth increase wage inequalities between couples? The case of France between 1982 and 2014
}

\author{
Milan Bouchet-Valat*
}

\begin{abstract}
It has often been argued that women's employment growth is a factor that contributes to the increase in inequalities between households due, in particular, to an alleged reinforcement of social homogamy. In contrast to this idea, an accounting approach to inequality decomposition, based on Insee's Labour Force surveys (enquêtes Emploi) shows that wage inequalities between couples aged 30 to 59 remained stable between 1982 and 2014 in France, whereas they would have increased had women's employment rate not risen.

This overall stability results from two converse developments, which are themselves linked to the strong growth in women's employment over this period: a fall in wage inequality between women and an increase in the correlation of partners' wages within couples. However, the almost uniform increase in women's employment rate, regardless of their partner's wage level, has limited the increase in the correlation of partners' wages and prevented an increase in wage inequalities between couples.
\end{abstract}

JEL codes : D10, D31, D63, J12, J22

Keywords : wage inequality, women's employment, couples, homogamy

\section{Reminder:}

The opinions and analyses in this article are those of the author(s) and do not necessarily reflect their institution's or Insee's views.
*National Institute for Demographic Studies (Ined) and Crest, Quantitative Sociology Laboratory (milan.bouchet-valat@ined.fr). The tables and the code that enable the analyses to be reproduced are available on the author's personal web page at http://bouchet-valat.site.ined.fr. 
W omen's employment rate has increased significantly in France since the 1960s. This trend, which continues to this day at a regular pace, has had significant repercussions for the sources of household income. Thus, between 1982 and 2014, the contribution of all women's wages to the total earnings of couples aged between 30 and 59 (excluding the self-employed and the retired) increased from $27 \%$ to $38 \%$ (see Figure I below).

A fairly significant increase in wage and income inequalities between individuals or between households has also been observed in France, primarily due to the strong growth in income at the top of the social structure (Landais, 2007 [2008]; Amar, 2010; Solard, 2010; Godechot, 2012, 2013 [2014]; Piketty, 2013 [2014]). It is then interesting to investigate, as did the Organisation for Economic Cooperation and Development (OECD, 2008, 2011) recently, whether the increase in the employment rate of women, by reinforcing the association between partners' wages (consequence of social homogamy), has contributed to strengthening this trend.

In a somewhat counter-intuitive manner, this paper provides a negative response to this question. Wage inequalities between couples aged between 30 and 59 (excluding the self-employed and the retired) remained fairly stable in France between 1982 and 2014, and even declined slightly above the median. This trend results mainly from an equalising effect of women's employment growth, whereas the slight fall in men's employment rate has tended to exacerbate inequalities between couples.

This overall development masks contrasting trends depending on the part of the wage distribution of couples taken into consideration. Thus, although the increase in the employment rate of women has had an equalising effect on the overall distribution, the fall in the employment rate of men has led to more inequality below the median.

In France, the increase in women's wages has not been accompanied by a sufficient strengthening of the association between spouses' wages within couples to increase inequalities between couples, unlike in the United States (Cancian \& Reed, 1998; Hyslop, 2001; Schwartz, 2010). This phenomenon can be explained by the fact that the increase in the employment rate of women has occurred at the same pace regardless of the spouse's wage decile (with the notable exception of the first decile, the inactive population and the unemployed). The association between spouses' wages has even weakened at the top of the distribution.

These trends are consistent with those also observed in France with respect to wage inequalities and the choice of spouse. Thus, contrary to popular belief, if we disregard the top of the distribution, we have seen a slight fall in wage inequalities since the 1960's (Verdugo et al., 2012; Charnoz et al., 2013 for the wages of men working full time in the private sector; Verdugo, 2014), whereas inequalities in the standard of living have been fairly stable since the 1990's (Pujol and Tomasini, 2009; Boiron et al., 2016). In addition, the similarity between spouses (social homogamy) has tended to weaken in terms of qualifications and occupation for several decades now (Vanderschelden, 2006; Bouchet-Valat, 2014).

The study is based on the annual data from the French Labour Force surveys (Insee's enquêtes Emploi) since 1982, and relates solely to wages (Box 1). Couples where one of the partners is self-employed or retired are excluded. In order to avoid excessively cumbersome formulations, we will from now on define 'employment' as receiving a wage; 'employment rate' will thus designate the proportion of individuals within this scope that receive a salary. No distinction is made between full-time and part-time wage earners, and the absence of a wage is regarded as a zero wage. The analyses thus focus on the wage actually received, which is the result of both decisions to engage in active employment that are more or less freely chosen or forced upon them (and frequently linked to family situations, see Meron \& Maruani, 2012, chapter 2), and of a more or less favourable position in terms of hourly wages. Although not taking into account other types of income, including capital income, means disregarding a significant aspect of the increase in income inequalities (Landais, 2007 [2008]; Piketty, 2013 [2014]), this approach is fully relevant to the study, in particular, of the effects of the growth in women's employment on the link between partners' incomes and thus on inequalities between couples.

We first present an international and French literature review. We then show, using a decomposition of the coefficient of variation, that the growth in women's employment rate has not further exacerbated wage inequalities between couples. This result stems in particular from the fact that the social distribution of women's 
employment has remained fairly stable, thus limiting the increase in the correlation between partners' wages. Lastly, using a decomposition method based on different counterfactual scenarios developed using log-linear models, we highlight contrasted effects of women's and men's employment trends on inequalities depending on the area of the wage distribution under consideration, as well as the fairly limited role played by the change in the association between partners' wages.

\section{Women's employment, homogamy and income inequalities between couples in the literature}

The question of the changing association between partners' wages within a couple and its effects on inequalities has been addressed mainly in work relating to the United States: research initially focused on evaluating the effect of the increase in women's participation in the labour force on inequalities between households since the 1960s. The US context, which is characterised by a significant increase in educational homogamy frequently perceived as a risk for the cohesion of US society (Breen \& Salazar, 2011), is clearly fairly different from the context in France. Women's growing participation in the labour market has been regarded as one of the factors of the increase in inequalities observed in many countries across the world (Blossfeld \& Buchholz, 2009; Esping-Andersen, 2007). Contrary to this view, all studies conclude that women's employment growth has in fact tended to limit the increase in income inequalities in the United States (Cancian \& Reed, 1998, 1999; Reed \& Cancian, 2001; Devereux, 2004; Pencavel, 2006; Western et al., 2008; Daly

Box 1

\section{SOURCE, SCOPE AND DEFINITION OF WAGE}

This study is based on the series of French Labour Force Surveys (Enquêtes Emploi) conducted by Insee from 1982 to 2014, and covers all cohabiting couples (whether married or not) where both partners are aged between 30 and 59 and neither is self-employed or retired. Restricting the sample to individuals aged at least 30 allows us to limit as far as possible the effects of recent cohorts first cohabiting and entering the labour market at a more advanced age, which would require separate analyses. Over the whole period, around a third of men and half of women aged between 20 and 30 cohabit with a partner in any given year, while this rate exceeds three quarters for individuals of both sexes in their thirties; this share has fallen by 6 to 8 percentage points over the years (Bouchet-Valat, 2014, p. 331-332 ). Moreover, although the employment rate of individuals aged 20 to 30 has fallen significantly since 1982 both among men and women, it has been more stable among men in their thirties and has increased among women in their thirties or in otherage brackets (Insee, 2016).

The Labour Force Surveys provide annual data and homogeneous monthly wages based on large samples. However, monthly wages are self-reported. While this can give rise to a difference in wage levels compared to the wage data from administrative sources, a comparison with the wages reported by employers in the Annual Declarations of Social Data (DADS) shows that the trends are similar to a large extent.

The Labour Force Surveys questionnaire asks respondents to specify their monthly wage in the month preceding the survey, as well as any supplementary earnings received annually (bonuses, $13^{\text {th }}$ month's salary, etc.). The respondents have the option of not responding, or either of indicating a wage bracket rather than an amount, in which cases Insee imputes a value computed on the basis of other available variables.

As wages were provided only in the form of brackets between 1982 and 1989, we have imputed the wages for these years using the simulated residual method (O'Prey, 2009, p. 17). The imputation model, which is applied separately to men and women (either cohabiting with a partner or not), takes account of the interval censoring linked to the wage brackets, and assumes a log-normal wage distribution. The variables taken into account are the regular working hours, seniority combined with the type of contract, age (and its square), the socio-professional category (PCS level 3), the level of qualifications, the urban area size and the region of residence.

Due to the significant fluctuations linked to the sampling at the top of the wage distribution, the wages in each year that exceed the $995^{\text {th }}$ thousandth (i.e., $0.5 \%$ of cases) have been pegged back to that level. The sample size does not allow for this group (around 40 individuals per year) to be studied with precision from one year to the next.

Only those actually employed at the time of the survey are asked about their wages. We have attributed a wage equal to zero to the unemployed and the inactive population (of whom less than $3 \%$ declare a wage). The sample, restricted to individuals taking part for the first time in the survey, comprises between 5,300 and 7,000 couples per year prior to 2009 and between 7,700 and 8,700 since then, which makes a total of 217,000 couples. 
\& Valletta, 2006; Hryshko et al., 2014) and in all of the OECD countries, particularly in France (OECD, 2011, p. 226 [p. 207]; Harkness, 2013; these two comparative studies are based on the Luxembourg Income Study, which comprises the Family Budget survey for France).

The specific role of changes in homogamy is more disputed. In France, an analysis of all of the wages earned by couples during their lives (Courtioux \& Lignon, 2015a) recently showed that educational homogamy only partially mitigates the equalising effect of couple formation. The Gini coefficient for wages earned by individuals from the same generation during the whole of their lives falls by $12 \%$ if we consider couples rather than individuals taken in isolation. This fall would be greater, by 3 percentage points for women and 7 percentage points for men, if couples were formed randomly (no homogamy). Based on a different method, another study (Frémeaux \& Lefranc, 2015) estimated that educational homogamy causes a $3 \%$ to $10 \%$ increase in inequalities between the annual wages of couples. However, these studies disregard the issue of changes over time. Given the weakening of homogamy in terms of education and social class, as highlighted by the research on France (Vanderschelden, 2006; Bouchet-Valat, 2014), it seems unlikely that changes to this factor could have contributed significantly to an increase in inequalities between households in recent decades.

Most of the literature available for other countries confirms that, contrary to popular belief, educational homogamy only forms a fairly loose, albeit real, link with the association between partners' wages ${ }^{1}$, and its increase has only had negligible - or even negative - impacts on the increase in wage inequalities in many countries (Worner, 2006 for Australia; Western et al., 2008 ; Breen \& Salazar, 2010, 2011 for the United States and the United Kingdom; Breen \& Andersen, 2012 for Denmark ; Eika et al., 2014 for the United States and Norway).

We thus focus here on measuring the effect of the increase in the association between partners' wages on inequalities between couples: we believe that this question must be addressed prior to the issue of the influence of variations in

1. Though a study asserting that the increase in educational homogamy explains a significant share of the growth in inequalities between households in the United States has been given some credence, the results have been subject to a corrigendum that significantly mitigates this assertion (Greenwood et al., 2014). educational homogamy, which only has an indirect link with partners' wages. Existing studies on this issue have noted either that the increase in the association between partners' incomes explains between $15 \%$ and $30 \%$ of the total increase in inequalities in the United States, depending on the periods studied and the methods used (Karoly \& Burtless, 1995; Burtless, 1999; Cancian \& Reed, 1999; Hyslop, 2001; Schwartz, 2010), or that it makes an even more modest contribution to this (Cancian \& Reed, 1998; Hryshko et al., 2014 for the United States; OECD, 2011, p. 226 [p. 207] for the member countries of the organisation; Funes Leal, 2015 for Argentina). To be more precise, this factor is said to have mainly contributed to the increase in wage inequalities in the United States in the 1980 s, but only to a negligible extent since then (Larrimore, 2014).

In the case of France, it would appear that the equalising effect of the growth in women's employment outweighs the opposite effect of a potential increase in the association between partners' wages. Indeed, it is the former phenomenon which constitutes the major change over the period under consideration.

The contribution of this study is first and foremost to analyse the changes over time, whereas the existing research for France (Frémeaux \& Lefranc, 2015; Courtioux \& Lignon, 2015a) focuses on a single point in time (either a cohort or a survey year). This historical perspective is necessary to identify the impact of the growth in women's employment on inequalities. Like Frémeaux and Lefranc, we study the inequalities between the wages earned by couples, whereas the Courtioux and Lignon study focuses on the inequalities that can be attributed to educational homogamy (see Courtioux \& Lignon, 2015b, for a presentation of the different methods used by this latter approach).

Courtioux and Lignon (2015a) attempted to reconstruct the income of members of the same cohort over the course of their lives using dynamic microsimulation models. Put more simply, the advantage of the analysis of wages at the time of the survey used here is that it describes the association between partners' wages actually observed each year, without having to make assumptions in order to reconstruct the composition of the couples taking account of such factors as educational homogamy. However, it does not take account of the individuals' income over the course of their lives, or unpartnered individuals, or the 
household size (which allows standards of living to be calculated).

Frémeaux and Lefranc (2015) focused on annual wages - actually received and in full-time equivalent - whereas this paper limits itself to monthly wages. This restriction enables us to cover a longer time span thanks to the Labour Force surveys. However, it introduces wage variations over a short period, which would be smoothed by using annual or multi-annual averages. This restriction probably leads to an underestimation of the association between partners' wages; however, the estimations of the contributions of the different factors to the inequalities and their changes over time are barely affected by this bias (Frémeaux \& Lefranc, 2015, p. 11; Hryshko et al., 2014, p. 771).

Lastly, we should point out that the accounting approach (Courtioux \& Lignon, 2015b) that we adopt is designed to provide a decomposition of the effects of the various factors on homogamy based on the assumption that the behaviour of the individuals remains unchanged. This is thus a descriptive and illustrative exercise, but not one designed to identify causal links.

\section{Women's employment growth has not exacerbated wage inequalities between couples}

\section{The growth in women's employment and wages in France since 1982}

The growth in women's employment, which has been under way since the start of the 1960s, has been very marked in France since 1982. The strong growth in the contribution of women to the total wages of couples mentioned in the introduction has resulted from a combination of two trends: firstly, an increase in the employment rate, i.e., from the viewpoint adopted here, the growth in the share of women who earn a wage; and secondly, wage growth among women in employment.

The growth trend of women's employment rate is well-documented: the share of women aged between 30 and 59 who live with a partner (excluding the self-employed and the retired) and earn a wage increased from 51\% in 1982 to $78 \%$ in 2014 (Figure I). However, another development has been less visible: in parallel to the increase in women's contribution to couples' wages, the share of women earning a higher wage than their partner has doubled, increasing from $12 \%$ to $24 \%$ over the same period (see also Morin, 2014).

This last trend is of course attributable to the increase in the employment rate of women, as well as to a very slight increase in working women's wages compared to those of men (Minni, 2015): the mean wage of women living with a partner was $36 \%$ lower than that of men living with a partner at the start of the period, and $28 \%$ lower at the end of the period. This marginal development was more marked at the bottom of the distribution (a decrease from a $67 \%$ gap to a $49 \%$ gap for the first decile).

It should be noted that this change occurred despite a strong growth in the share of part-time work among women (Afsa Essafi \& Buffeteau, 2006), which increased from $19 \%$ in 1982 to $32 \%$ in 1999 , and has remained stable at that level since then (Insee, 2016). This rate has also increased among men, from $3 \%$ to $8 \%$, although the overall level has remained low. Conversely, the rate of unemployment has increased more among men (for whom it doubled from 5\% in 1982 to $10 \%$ in 2014) than among women (Cabannes, 2014; Insee, 2016). It was indeed already quite high among women $(8 \%$ in 1982), and though it reached almost $12 \%$ in the mid 1990s, it has since fallen back to the same level as for men (10\% in 2014). The differences between men and women in terms of part-time work and unemployment have thus followed opposite trends, whereas the increase in the activity rate and the employment rate have significantly boosted growth in women's wages compared to those of men.

Growth in women's wages over the last thirty years have been very marked. However, even if the very stable pace of the increase observed since 1982 were to be maintained, the total amount of women's wages would account for half of the total wages of couples only by around 2045. It is moreover unlikely that this will happen by then, as the rate of employment among women living with a partner, which is the main factor driving his change, would (based on the same assumption) reach 100\% a decade earlier, and would probably become stable well before then. For the same reasons, it is far from guaranteed that half of women will receive a higher wage than that of their partner some time during the 21 st century: even based on the very optimistic projection that the past 
pace would continue, this event would only occur in around 2080.

Moreover, the growth in women's employment has not prevented their less favourable situation on the labour market from continuing (Meron, 2008; Albouy et al. 2012): greater job insecurity, part-time work, lower wages due to the structure of these jobs (segregation between sectors and professions), but also when they perform the same job as a man. These caveats and the uncertainty about future trends should not, however, mask the significance of the changes that have occurred since the 1980s.

\section{A reduction in wage inequalities among women and the stability of inequalities between couples}

Has the 10 percentage-point increase in women's wages as a share of the total wages of couples led to a reduction in inequalities between couples? In order to answer this question in this section, we decompose the inequalities between the wages of couples, and their changes over time, into three different sources. To do this, we measure the overall level of inequalities using the coefficient of variation, which offers definition which is easily interpretable in terms of the dispersion around the mean. It is defined as the ratio between the standard deviation $\sigma$ and the mean $\mu$ of a distribution, i.e.:

$$
C V=\frac{\sigma}{\mu}
$$

The change in the inequality between the total wages of couples (with a wage of zero attributed to the unemployed and the inactive population) is presented in Figure II. We observe a fluctuation without a clear trend, which culminates, in 2014, in a level of inequality that is close to that observed in 1982. The decomposition of the coefficient of variation will enable us to understand this result.

The square of the coefficient of variation can be expressed as the sum of three terms, each of which corresponds to a clearly identified source of income:

$$
\begin{aligned}
C V^{2}= & \left(1-S_{f}\right)^{2} C V_{h}^{2}+S_{f}^{2} C V_{f}^{2} \\
& +2 \rho_{h f} S_{f}\left(1-S_{f}\right) C V_{h} C V_{f}
\end{aligned}
$$

Figure I

Growth in the wages of women living with a partner since 1982 via three indicators

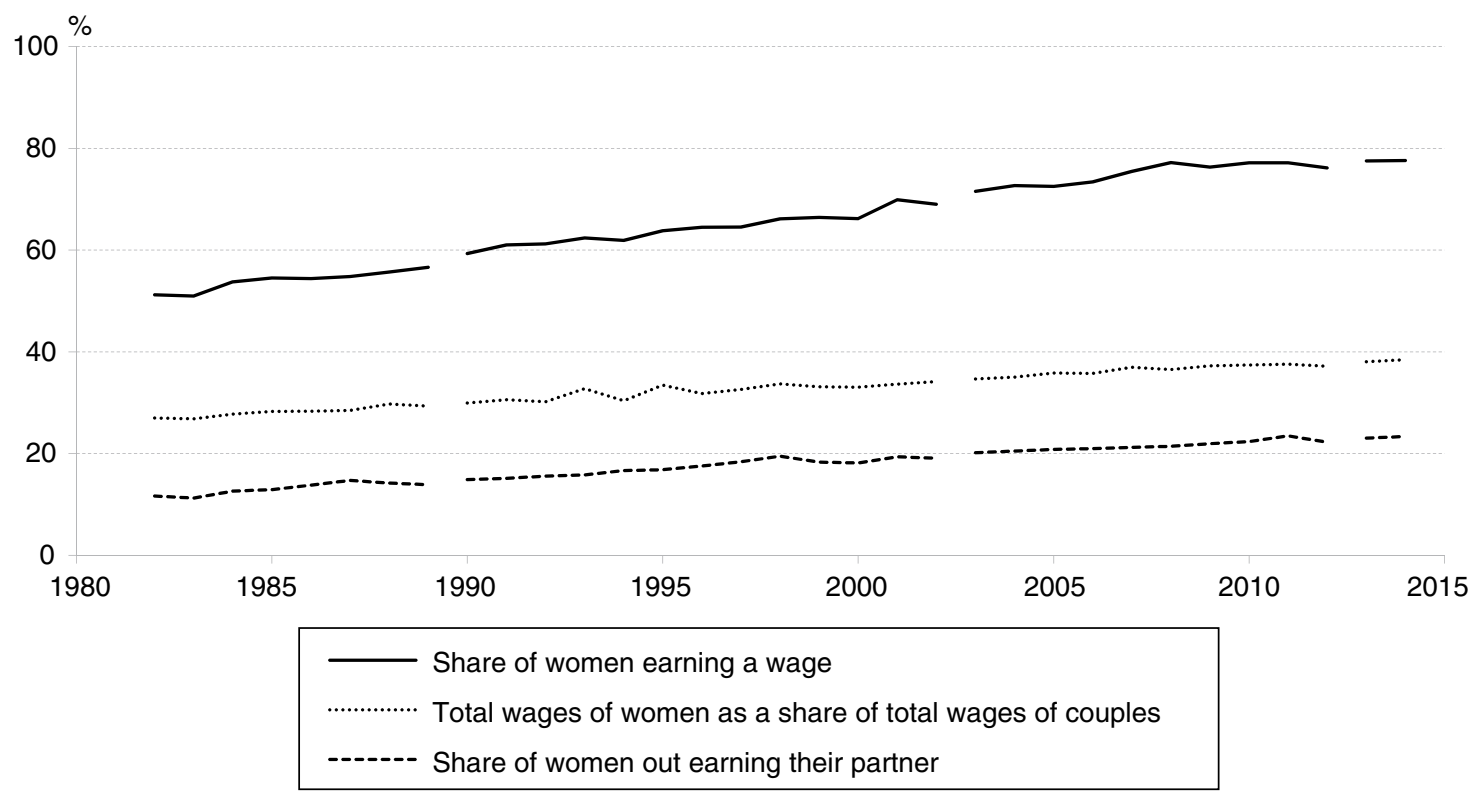

Note: the unemployed and the inactive are included and are attributed a wage equal to zero.

Reading note: in 1982, 48\% of women aged between 30 and 59 and living with a partner were earning a wage, whereas these wages only accounted for $28 \%$ of the total wages of couples, and only $13 \%$ of them were earning more than their partner.

Coverage: cohabiting men and women, where the partners are aged between 30 and 59 and neither is self-employed or retired. Source: Insee, Labour Force Surveys (enquêtes Emploi), 1982-2014. 
$S_{f}$ measures women's wages as a share of the total wages of couples, $C V_{h}$ and $C V_{f}$ (with $\mathrm{h}$ for men, $f$ for women) are respectively the coefficient of variation for men's and women's wages, and $\rho_{h f}$ corresponds to the correlation between partners' wages within couples. Inequality between couples is thus more pronounced when the inequality between individuals of the same sex is high; when the gender most affected by the inequality contributes significantly to the total wages of couples; and when the correlation between partners' wages is strong.

According to this equation, the contribution of each sex to inequality between couples can be evaluated in relation to (at least) three benchmark situations, known as counterfactual situations, which allow for three different causes of the changes in inequalities to be identified (Cancian \& Reed, 1998, p. 74). First situation: if only the individuals from one sex contributed to the total wages of couples, as the members of the other sex would all be inactive or unemployed, the level of inequalities between couples would correspond respectively to $C V_{h}$ or $C V_{f}$, depending on whether those actively working are men or women. Second situation: if the wages of the individuals from a given sex were all equal and, consequently, the inequality was attributable exclusively to the wages of the other sex, then the level of inequality between couples would be equal to $\left(1-S_{f}\right) C V_{h}$ or $S_{f} C V_{f}$, depending on whether the inequality stemmed from men or women. Third situation: if there were no correlation between partners' wages, the coefficient of variation would be equal to the square root of the sum of the terms $\left(1-S_{f}\right)^{2} C V_{h}^{2}$ and $S_{f}^{2} C V_{f}^{2}$.

Thus, the association between partners' wages potentially plays an important role in determining inequalities between couples. Based on a hypothetical scenario, which was unrealistic in 1982, but which has become increasingly credible over time, where wage inequalities are the same among men and among women and where both sexes contribute equally to the total wage volume, moving from no correlation to a perfect

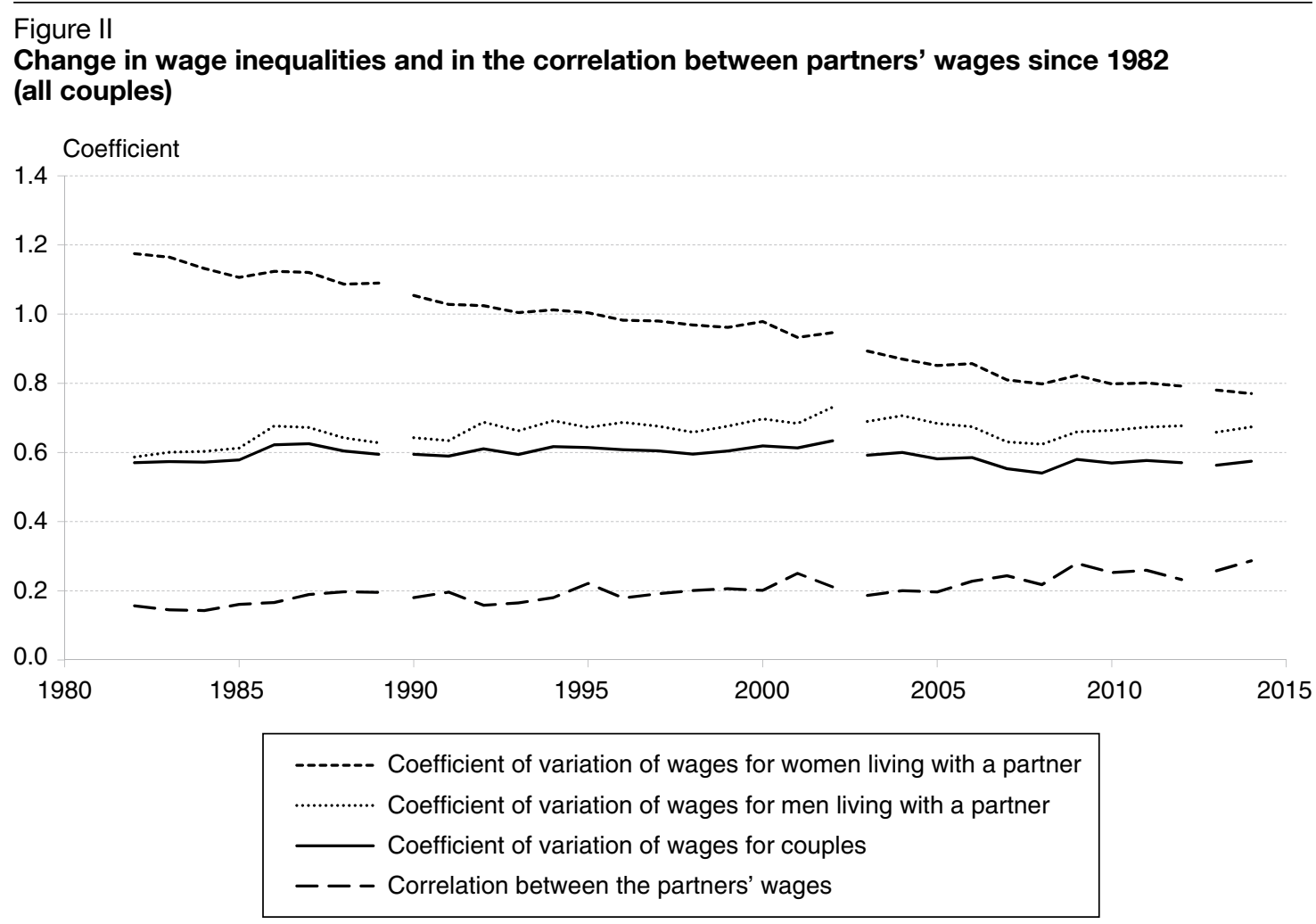

Note: the unemployed and the inactive are included and are attributed a wage equal to zero.

Reading note: the coefficient of variation of wages for women living with a partner (including those who have a zero wage) fell from 1.17 in 1982 to 0.77 in 2014.

Coverage: cohabiting men and women, where the partners are aged between 30 and 59 and neither is self-employed or retired.

Source: Insee, Labour Force Surveys (enquêtes Emploi), 1982-2014. 
correlation between partners' wages would amount exactly to doubling the level of inequalities between couples. Such a radical change in the correlation is fairly improbable: conversely, the correlation between partners' wages is usually too weak to have such strong impacts on inequalities ${ }^{2}$.

Thus, the stability of the overall inequality results from the fact that the different components of the equation either remained fairly stable or followed opposite trends, which cancelled each other out to a large extent (cf. Figure II). Firstly, despite a fairly clear increasing trend up until the 2000's, inequality between men's wages $\left(C V_{h}\right)$ changed little, and fluctuated around a coefficient of variation of $0.7^{3}$. On the other hand, inequality between women's wages $\left(C V_{f}\right)$ has significantly fallen, with the coefficient of variation falling from 1.17 to 0.77 , and has clearly moved towards parity with the level among men. This change is attributable to the growth in women's employment, which has caused the wage of a significant proportion of the sample to increase from zero (inactivity) to a level that is very likely to be closer to the mean (Pasqua, 2002). This decrease in inequality between women, coupled with the significant increase in women's wages as a share of the wages of couples $\left(S_{f}\right)$, has had a very clear equalising effect (cf. Figure I).

Although this change is a mechanical consequence of the increase in the employment rate of women, it should be noted that it has not been accompanied by a sufficient increase in the third term of the equation - the correlation between partners' wages - to reverse the equalising trend: the growth in this correlation (taking account of both active and inactive individuals) from 0.16 in 1982 to 0.26 in 2013 has just been sufficient to offset the effects of the lowering of the inequality between women ${ }^{4}$. This level of correlation, which is slightly higher than that already observed in existing

2. This mechanism corresponds to the standard phenomenon of regression towards the mean (Verbakel, 2008, p. 132), based on which an individual receiving a wage far removed from the mean (either very high or very low, or zero) is very unlikely to form a couple with a person who receives such an outlying wage.

3. The increase in wage inequalities between men from 1982 to 1986, which occurred exclusively above the median, has already been observed in other works based on administrative data (Charnoz et al., 2013, p. 73; Verdugo, 2014, p. 135). However, the existing studies point instead to a fall in wage inequalities between men since the 1960's, excluding unemployment and inactivity (Verdugo, 2014; Verdugo et al., 2012).

4. The reality of the sudden transition to a correlation of 0.29 in 2014 needs to be confirmed by future surveys. studies for France (Frémeaux \& Lefranc, 2015, p. 10), is significantly higher than that reported by several authors for the United States. In the US, the correlation was slightly negative ${ }^{5}$ prior to 1980 , and has stood at around 0.1 in recent years (Schwartz, 2010, p. 1540; Cancian \& Reed, 1998, p. 76; Reed \& Cancian, 2012, p. 10). This can be seen as a reflection of the French model of participation of women in the labour market, where full-time work is more prominent than in other countries (Meron \& Maruani, 2012).

The correlation between partners' wages within dual-earner couples (who, excluding the unemployed and the retired, accounted for $48 \%$ of couples in 1982 and $68 \%$ in 2014) is higher than for all couples: for the period under consideration, it stands at around 0.35 to 0.40 (Figure III). This gap has also been observed in the United States (Schwartz, 2010), where there is once again a less strong correlation than in France. However, this correlation is still fairly modest. Thus, the growth in the correlation between partners' wages is not found among dual-earner couples: the correlation here has fluctuated without any clear trend since 1982 (Figure III). As a result of this relative stability, wage inequality between dual-earner couples has been fairly much in line with the changes in wage inequalities between men and women living in a couple: it increased by $19 \%$ through to 2002 , then fell back down to its initial level. Very different mechanisms have thus given rise to fairly similar changes, whether we take account of all couples or only dual-earner couples.

\section{Almost uniform growth in women's employment at all partner wage levels}

The effect of the increase in the share of dual-earner couples on the correlation between partners' wages among all couples depends to a large extent on the link between women's employment and the partner's wage level (Pasqua, 2002). Thus, in the United States, the increase in the correlation between partners' wages is attributable to a great extent to the fact that the negative relationship between men's

5. This was due, in particular, to the low rate of employment of wives whose partner belongs to the top deciles. 
wages and employment of his partner has gradually disappeared, giving way to an inverted $\mathrm{U}$ curve according to which the middle classes have the highest levels of women's employment (Schwartz, 2010, p. 1541).

However, the French situation appears to be fairly different (Figure IV, left-hand graph). As early as 1982, the highest employment rate of women (at around $60 \%$ ) could be found among the partners of men belonging to the seventh wage decile (confirming the results of Frémeaux \& Lefranc, 2015, p. 15). Conversely, its level was almost as low for the top decile (11 percentage points below the maximum) as it was for the bottom decile (13 percentage points below). However, women whose partner has no wage stood out clearly from the rest with an employment rate that was 18 percentage points below the maximum.

In the United States at the same period, only the upper deciles stood out with an employment rate of women that was clearly lower than the others, with the lower deciles joining them gradually only after this date. France seems thus to have experienced the change observed in the United States at an earlier date: in France, women's employment already caused a higher increase in wages for couples in the middle of the distribution than for couples at the outer boundaries of the distribution.

In France, between 1982 and 2014, the employment rate of women increased at the same pace regardless of the partner's wage decile, with the notable exception the lower decile and the inactive population and the unemployed, for whom the gap with the highest employment rate increased to 18 and 28 percentage points respectively. Thus, the effects of the growth in women's employment on the correlation between partners' wages (with a wage of zero attributed to the inactive and the unemployed) continued to be limited and were not sufficient to increase inequalities between couples.

The picture is somewhat different for men (Figure IV, right-hand graph). Overall, we note a slight fall in the employment rate over time, which contrasts with the increase observed among women. Moreover, the employment rate of men increases along with their partner's wage up to the median, and becomes

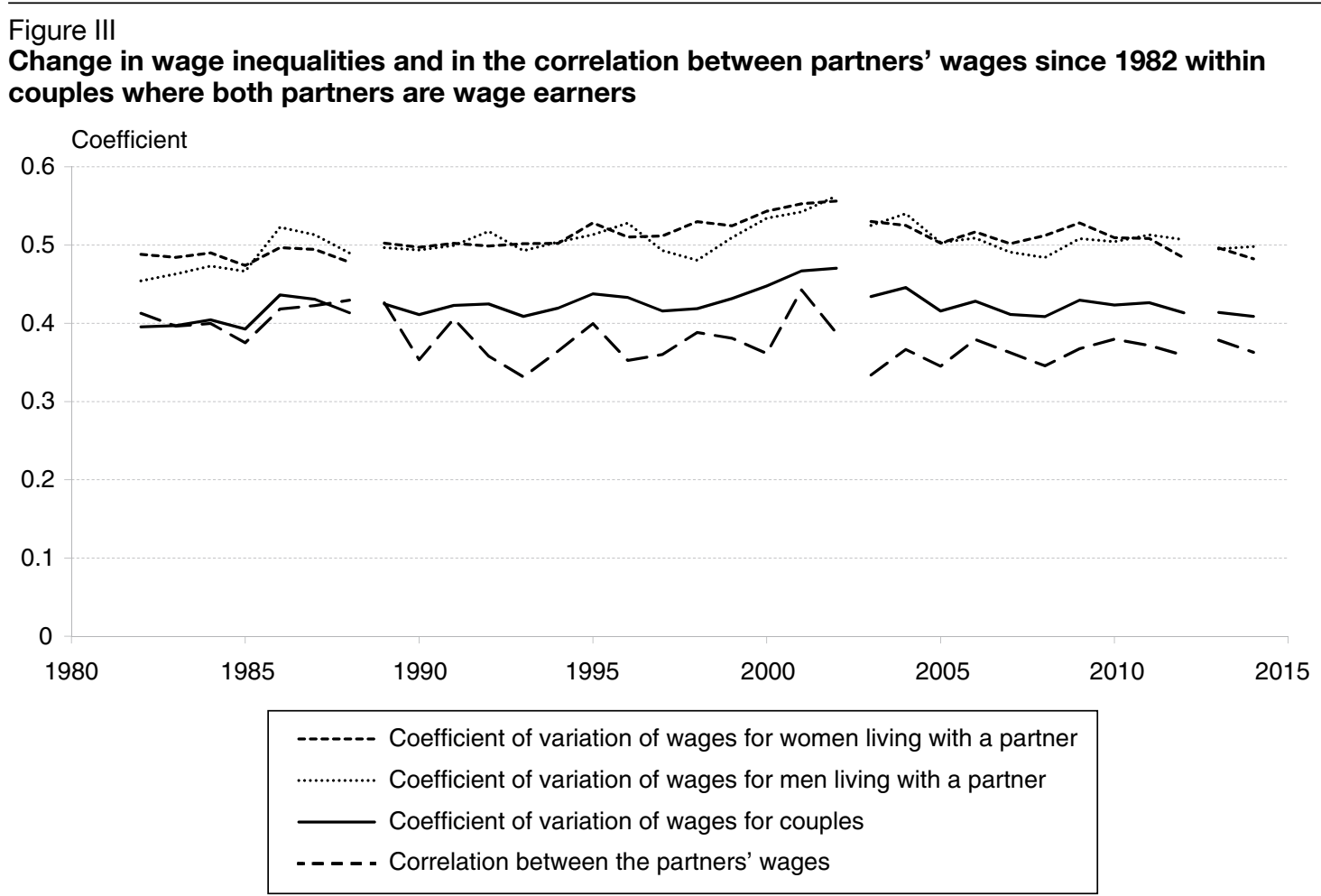

Reading note: the coefficient of variation of wages for women living with a partner, where both partners are wage earners, has remained fairly stable, falling from 0.49 in 1982 to 0.48 in 2014 with a peak of 0.56 in 2002.

Coverage: cohabiting men and women, where the partners are aged between 30 and 59 and both earn a wage and neither is self-employed or retired.

Source: Insee, Labour Force Surveys (enquêtes Emploi), 1982-2014. 
stable thereafter. However, as is the case among women, the group in which the female partners have no wage stands out quite clearly from the others. The gap between the employment rate of this group and the maximum rate increased significantly over time (from 4 to 16 percentage points), reflecting a certain trend towards the polarisation of employment between couples (Ravel, 2007).

Thus, unlike in the United States, the change in the employment rate of women has not constituted a significant cause of change in the correlation between partners' wages. The almost general increase in the employment rate of women, regardless of the partner's wage, has limited the increase in the correlation between partners' wages, thus avoided an increase in inequalities between couples. However, whether for women or men, we note a fall in the employment rate of the partners of individuals earning the lowest wages, or no wage, the effect of which is necessarily to increase inequality. In the next section, a more detailed decomposition of inequality will enable us to evaluate the effects of these trends at different points of the distribution of couples' wages.

\section{A fall in inequalities that has not benefited couples situated just below the median}

\section{Diverging trends depending on the part of the distribution taken into consideration}

The decomposition of the coefficient of variation described in the last section has the advantage of being very simple. However, it does not allow us to examine whether the effects highlighted were uniform throughout the whole wage distribution, or evaluate the change in inequalities that would have been observed in other counterfactual situations than those already mentioned. In this section, we draw on the approach adopted by Schwartz (2010), which consists in modelling the joint wages of both partners using log-linear models (Agresti, 2002). These models, the parameters of which are subjected to constraints, serve to simulate several counterfactual situations by imposing constraints on parameters, which makes it possible to evaluate the contribution of each of the different trends to changing inequalities between couples.

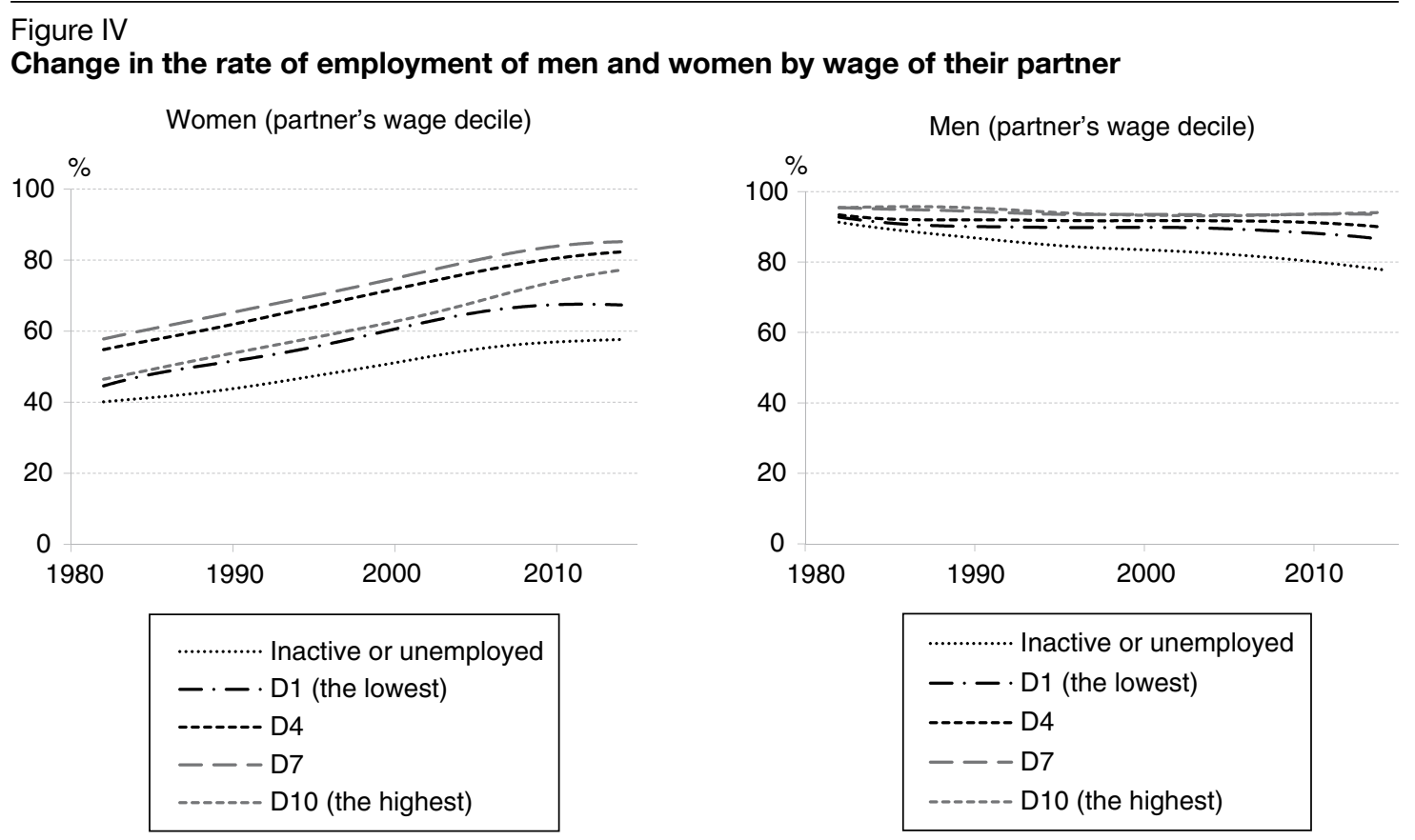

Note: the unemployed and the inactive are included in the scope and are attributed a zero wage. The curves are smoothed using a local regression of degree 1 (LOESS).

Reading note: in 1985, within couples aged 30 to $59,58 \%$ of women partnered with men in the 7 th men's wage decile were in employment.

Coverage: cohabiting men and women, where the partners are aged between 30 and 59 and neither is self-employed or retired. Source: Insee, Labour Force Surveys (enquêtes Emploi), 1982-2014. 
This decomposition, which is far more flexible than the previous one, is no longer necessarily limited to the coefficient of variation. In order to study whether the changes differed depending on the part of the distribution of the couples' wages under consideration, we make use of three new measures: the ratio between the upper decile and the median (D9/D5), the ratio between the median and the second decile $(\mathrm{D} 5 / \mathrm{D} 2)^{6}$, as well as the share of couples where neither partner has a wage.

The added value of this more detailed approach can be seen in Figure V, where we can observe the very different changes in the two interdecile ratios. Inequality above the median (D9/D5) increased a little in the 1980's, then decreased more significantly by $11 \%$ between 1986 and 2014. Inequality below the median (D5/D2) increased by $8 \%$ up until 1994 and then fluctuated or fell slightly thereafter. Lastly, the share

6. It is often the first decile (D1) that is considered rather than the second. This choice would be problematic here insofar as, for some years, around $10 \%$ of couples have no wage: the first decile is subject to irregular changes linked to the variations in the very low wages depending on the economic situation and the unemployment rate. Since inequality at the bottom of the distribution is already reflected in the share of couples with no wage, we deemed it preferable to make use of the second decile, where the changes are more regular. of couples with no wage increased from $3.9 \%$ to $6.9 \%$ between 1982 and 1987 , then peaked again during the 1990's and fell again a little in the 2000's, before increasing again after 2008 .

Thus, the stability of inequality between couples observed above (Figure II) masks diverging trends. Although we have noted a fall in the ratio of the median to the upper deciles ${ }^{7}$, the relative situation of the couples situated below the median first deteriorated a little, then improved, but not in a marked way. Below we will try to understand the factors behind this phenomenon.

\section{Decomposition method using log-linear modelling: six counterfactual scenarios}

The decomposition method proposed by Schwartz (2010) consists in: dividing the wage distribution for each sex observed each year

7. This fall occurred for all the deciles above the median.

Figure $\mathrm{V}$

Change in three indicators of inequality between couples since 1982

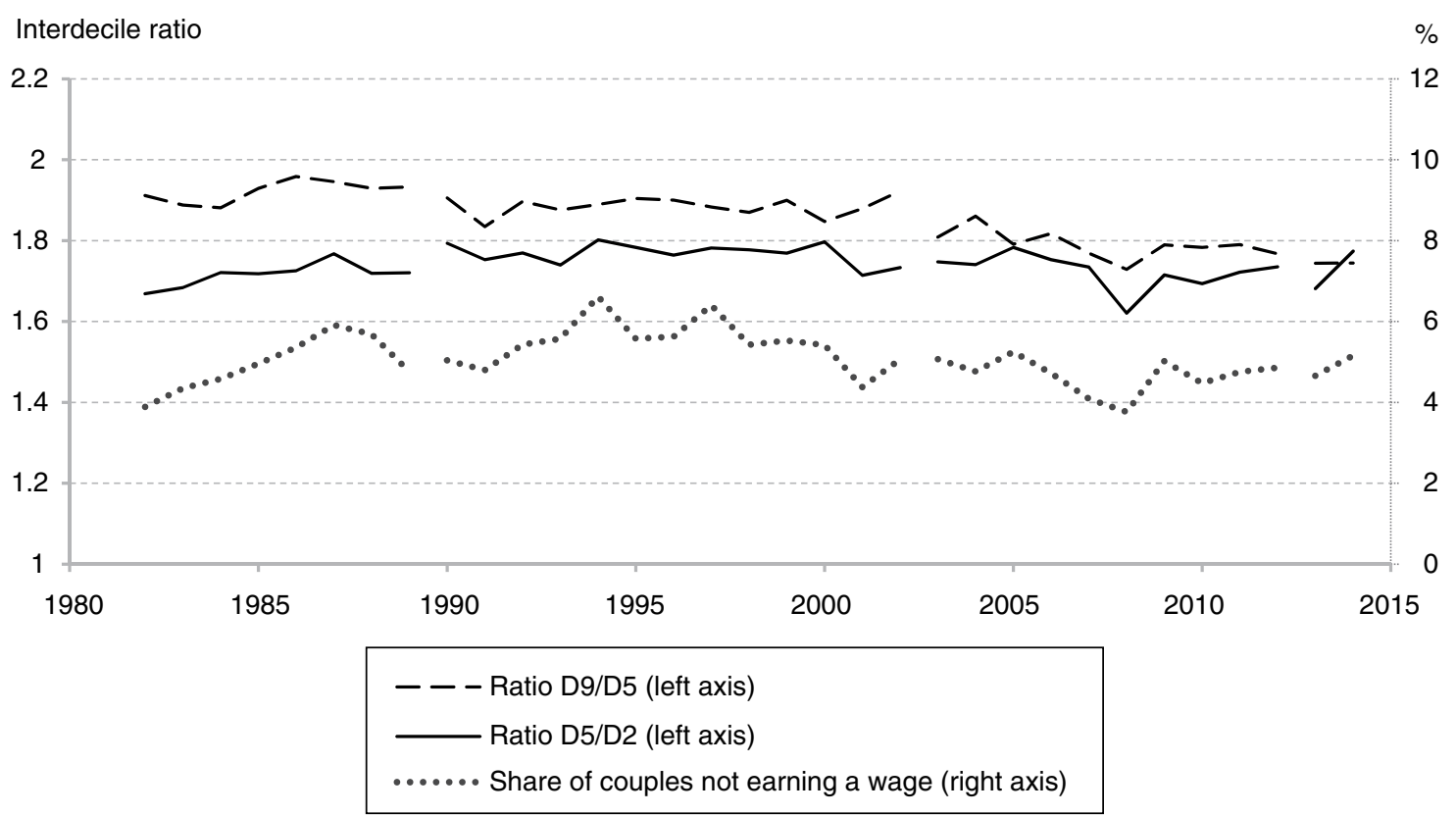

Note: the unemployed and the inactive are included and are attributed a zero wage.

Reading note: in 1986, the wage separating the wealthiest $10 \%$ of couples from the poorest $90 \%$ was equal to 1.9 times the median wage of couples.

Coverage: cohabiting men and women, where the partners are aged between 30 and 59 and neither is self-employed or retired.

Source: Insee, Labour Force Surveys (enquêtes Emploi), 1982-2014. 
into fairly fine quantiles, plus a group for the inactive and the unemployed; and constructing a three dimensional homogamy table, cross-classifying the quantiles to which each of the partners belong for each year. The coefficient of variation and the interdecile ratios can be re-calculated using this table by attributing to each individual the median wage for their quantile. In order to replicate fairly faithfully the values of the indices measured using raw data, we divide the distribution into 20 quantiles, each of which represents $5 \%$ of the individuals of each sex having earned a wage, plus a category comprising those that have not earned a wage.

The objective of this method is to use the table charting actually observed homogamy to model several tables, each of which corresponds to a counterfactual situation. We start with a model that imposes very strong assumptions on the association between partners' wages and on changes in this association; the assumptions are then relaxed gradually by introducing additional terms until we arrive at the changes actually observed: each model is an extension of the previous model (see Box 2). By comparing the values of the inequality indices obtained for each situation, we obtain an estimation of the contribution of the lifting of each of the assumptions to the inequalities and their changes over time.

The trends followed by the indicators between 1982 and 2014 for the different counterfactual scenarios are presented in Figure VI. The model-fit statistics for the log-linear models are listed in the appendix. It should just be noted that each more complex model constitutes a substantively and statistically significant

Box 2

\section{LOG-LINEAR MODELS USED FOR THE DECOMPOSITION}

The base model (model 1), which is the independence model, only includes the parameters needed to correctly reconstruct the share of couples in each wage quantile for men and women (including the zero wages) and for each year, but without any interaction between these three dimensions. With $m_{h f t}$ designating the counts predicted by the model for the cell at the intersection with line $h$ (quantile for men), column $f$ (quantile for women) and layer $t$ (survey year) in a table with dimensions $H \times F \times T$, this model is expressed as follows:

$$
M 1: \log m_{h f t}=\lambda+\lambda_{h}^{H}+\lambda_{f}^{F}+\lambda_{t}^{T}
$$

In addition, model 2 takes account of the change in the marginal distribution for women over time.

Model 3 adds that for men. They are expressed as follows:

$$
M 2: M 1+\lambda_{f t}^{F T} \quad \text { and } \quad M 3: M 2+\lambda_{h t}^{H T}
$$

Given that the populations for both sexes are segmented into quantiles each year, the marginal parameters have, at this stage, little effect (to within the approximation linked to the segmentation), with the exception of those that reflect the marginal shares of the inactive population and the unemployed: that is why this model amounts primarily to allowing these shares to vary over time.

Model 4 adds on to the specifications of the previous model the association between the inactivity or unemployment of the woman and the man's wage quantile, based on the assumption that the association remains stable over time. It is expressed as follows:

$$
M 4: M 3+\lambda_{h}^{H F_{0}} 1_{f=0}
$$

with $f=0$ indicating the absence of a wage for the woman (inactive or unemployed), and $1_{f=0}$ the corresponding indicative.

Model 5, which is the stability model, includes the full, but stable association between men's and women's wages. It thus incorporates the association between inactivity or unemployment and the partner's wage from the previous model (but which no longer appears as a specific term). It is expressed as follows:

$$
M 5: M 3+\lambda_{h f}^{H F}
$$

Although these five models assume that the association between partners' wages has remained stable in terms of odds ratios, the inequality indices may change over time, since they are not independent of the margins of the table.

Model 6 also allows the association between inactivity or unemployment of the woman and the man's wage quantile to vary linearly over time. It is expressed as follows:

$$
M 6: M 5+\left(\lambda^{F_{0}}+t \lambda^{F_{0} T}\right) \lambda_{h}^{H F_{0} T} 1_{f=0}
$$

with $f=0$ indicating the absence of a wage for the woman.

Finally, the last model corresponds to the data actually observed (saturated model). A comparison with the previous model allows us to measure the effects on inequalities between couples resulting from the change in the association between partners' wages in couples in which the woman is a wage earner. 
improvement on the previous one, as indicated by the Akaike Criterion Information, $\mathrm{AIC}^{8}$.

The first scenario (cf. model 1 in Box 2) assumes that there is no association between partners' wages or between the wage of one of the partners and the fact that the other is employed, and that the employment rate does not change over time. As a consequence, the only factor of inequality and change in inequalities taken into account here corresponds to the wage inequalities between men in employment, on the one hand, and between women in employment on the other, based on the assumption that the

8. However, the BIC (Bayesian Information Criterion) indicator, which is more parsimonious, does not give us reason to consider as worthy of note the respective contributions of models 3 and 6 , for which the share of couples classified in the wrong cell (dissimilarity index) decreases very little. couples are formed randomly. We can see that this factor has contributed very little to the changes in inequalities over time, as the indicators are stable (Figure VI, first row). The growth in women's employment and the changing association between partners' wages thus explain most of the changes.

In the second scenario, we once again assume that there is no link between the wage level of a partner and the status of the other partner, but we allow the employment rate to change over time. This specification allows us to evaluate the contribution of the increase in the employment rate of women to the change in inequalities between couples. The change in this sole factor brings about a very marked reduction in inequalities between 1982 and 2014, which shows very clearly the equalising role of women's employment.

Figure VI

Change in the variation coefficient, the ratios D9/D5 and D5/D2 and the share of couples not earning a wage between 1982 and 2014 in the different counter-factual situations

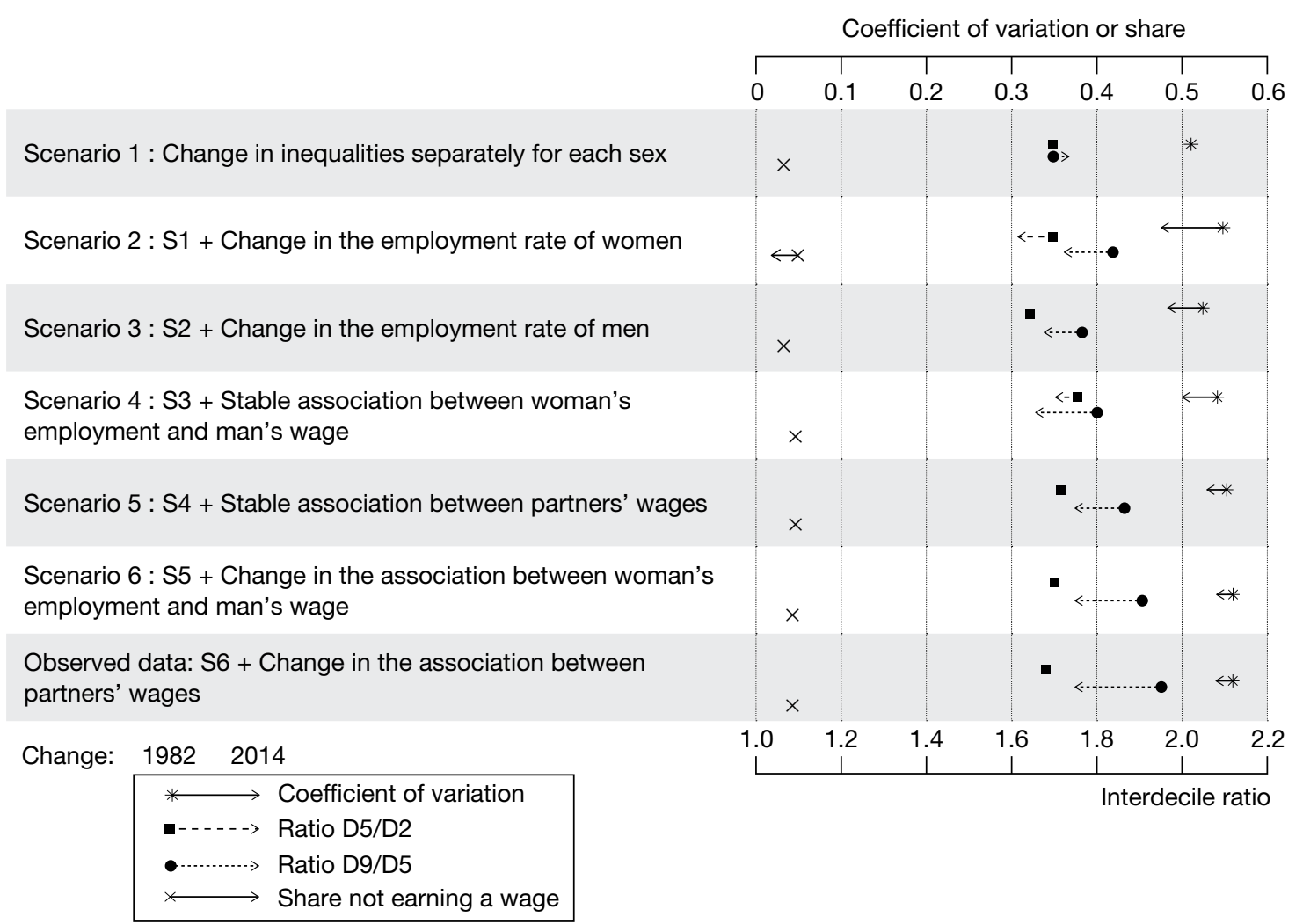

Note: the unemployed and the inactive are included and are attributed a zero wage. In order not to take account of the variations caused by the random sampling and the economic situation, the arrows do not directly represent the indices calculated based on the population stocks predicted by the models, but instead their value smoothed using a local regression of degree 2 (LOESS).

Reading note: if only the wage inequalities between men and between women had varied (first line), the overall level of the inequalities (coefficient of variation) would have remained stable (at 0.50) between 1982 and 2014.

Coverage: cohabiting men and women, where the partners are aged between 30 and 59 and neither is self-employed or retired. Source: Insee, Labour Force Surveys (enquêtes Emploi), 1982-2014. 
Thus, the inequalities (coefficient of variation) would have fallen by $14 \%$ overall, by $5 \%$ below the median (ratio D5/D2) and by $8 \%$ above the median (ratio D9/D5), whereas the share of couples with no wage would have decreased from $4.9 \%$ to $2.3 \%$.

Compared to the second scenario, the third adds the change in the employment rate of men over time. The slight fall in the employment rate of men mitigates the fall in inequalities predicted under the previous scenario ( $c f$. Figure IV). In particular, the overall inequality (coefficient of variation) would have fallen by only $7 \%$ (compared to $14 \%$ in the second scenario), and inequality below the median and the share of couples without wage would have remained stable. We can thus see that the growth in women's employment has offset the effects of the trend of increasing inequality occurring among men.

The fourth scenario is based on the assumption that the only association between partners' wages stems from the link between women's employment and the partner's wage, while also assuming that this link remains stable over time. It enables us to measure the effect on the inequalities and on their changes resulting from the differences in the employment rate of women depending on their partner's wage. This scenario does not substantially modify the changes over time predicted by the previous scenario. However, inequalities below the median (ratio D5/D2) and overall inequalities (coefficient of variation) are higher both in 1982 and 2014. This is due to the over-representation of women without wage among the couples in which the men are situated at the bottom of the wage distribution.

The fifth scenario expands on the previous one by assuming that there is an association between partners' wages (including no wage), but that this association remains stable over time. Contrary to expectations, this model (as well as the previous one) predicts a change in inequalities that is potentially different from model 3. Indeed, even though the association itself remains stable over time, the change in the distribution of men and women between employment and absence of employment moves the couples between areas of the homogamy table, which differ in terms of the intensity of the association between partners' wages. Thus, the comparison between the inequality predicted by this model and by the previous one enables us to evaluate the effect of the existence of an association between partners' wages on the changes in inequalities, even based on the assumption that this association remains stable. This scenario predicts greater inequalities that the previous one above the median (ratio D9/D5), as well as overall (coefficient of variation), due to the strong tendency for men and women earning the highest wages to form couples with each other. The deviation, however, is still modest: compared to the fourth scenario, the coefficient of variation is 5\% higher in 1982 and $9 \%$ in 2014 .

As for the time trends, they remain essentially the same as in the previous scenario. The lessening of overall inequalities (coefficient of variation) and those below the median (ratio $\mathrm{D} 5 / \mathrm{D} 2$ ) is slightly less marked, since the women that enter the labour market earn a wage that is closer to that of their partner than in the scenario that assumes a total absence of association. However, at the end of the day, the existence of a tendency towards homogamy only has a weak impact on changes to inequalities over time.

The sixth scenario introduces an initial source of change over time to the association between partners' wages: that of the link between the woman's employment and the man's wage, based on the assumption that the association between partners' wages remains stable. As could be expected due to the relative stability of the link between men's wages and women's employment already mentioned earlier, this scenario does not give rise to any notable differences compared to the previous one.

Finally, the last scenario corresponds to the table actually observed (saturated model). The difference compared to the previous scenario thus stems exclusively from the change over time in the association between partners' wages among couples where the woman is a wage earner. This comparison gives rise to a negative result, which warrants highlighting: contrary to the observation made in the United States, the change in the association between the wages of dual-earner couples (consequence of social homogamy) has no notable effect on inequalities between couples. However, we can note that the fall in the level of inequality above the median (ratio D9/D5) is slightly more marked, sign of a weakening of the association at the top of the distribution.

The finer decomposition performed in this section has shown that the increase in the employment rate of women has been by far the main factor contributing to the change in wage 
inequalities between couples (where neither of the partners is self-employed or retired) since 1982. The slight fall in the employment rate of men has, on the other hand, exacerbated inequalities, but not in a very marked way. Lastly, the changes in the different components of the link between partners' wages have played a fairly minor role.

Although the growth in women's employment has had an equalising effect on the distribution as a whole, the slight fall in the employment rate of men whose partner earns a low wage or has no wage, had a particularly marked disequalising effect below the median. The association between partners' wages also seems to have weakened a little at the top of the distribution. The combination of these three phenomena explains the contrasting changes in the indicators of inequality mentioned earlier: decrease in inequalities between couples above the median, stability elsewhere.

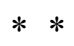

The results presented here, which contradict the idea that there is a general increase in both homogamy and wage inequalities, suggest extensions in three directions.

Firstly, inequalities are measured here in respect of wages only. However, the increase in economic inequalities stems for the most part from the change in the distribution of wealth and capital income (Landais, 2007 [2008]; Piketty,
2013 [2014]). Expanding the study to include all types of income and inheritance seems to be a promising approach, even though the data needed to study these are scarcer (Frémeaux, 2014). Moreover, it would appear essential to take account of transfer income - and particularly unemployment benefits - in order to refine the analysis of low incomes, which are only covered here in the form of the share of couples with no wage.

Secondly, we have adopted a purely cross-sectional approach, thus disregarding the significant variations in partners' incomes during their lives, including as a result of any periods of unemployment or inactivity (Courtioux \& Lignon, 2015a). Future research will have to endeavour to combine a study of the inequality changes over time with a longitudinal perspective at individual level in order to better take account of the possible compensations between partners for fluctuating activity status (inactivity, unemployment, working time).

Thirdly, our analysis focused exclusively on the individuals living with a partner in a given year. Based on the research from the United States (Karoly \& Burtless, 1995; Burtless, 1999; Cancian \& Reed, 1999; Reed \& Cancian, 2001; Daly \& Valletta, 2006; Western et al., 2008; Larrimore, 2014), we might think that the decrease in the share of persons living with a partner has exacerbated inequalities among all households. For example, single-parent families, which are more often women with low qualifications who are marginalised from the labour market (Chardon et al., 2008), may have seen their situation worsen in respect of the median wage of couples. 


\section{BIBLIOGRAPHY}

Afsa Essafi, C. \& Buffeteau, S. (2006). L'activité féminine en France : quelles évolutions récentes, quelles tendances pour l'avenir ? Économie et statistique, 398(1), 85-97.

https://www.insee.fr/fr/statistiques/1376348?som maire $=1376355$

Agresti, A. (2002). Categorical Data Analysis ( $2^{\mathrm{e}}$ éd.). New York: Wiley.

Albouy, V., Djider, Z. \& Mainguené, A. (2012). Activité, emploi, salaires et retraites : la convergence des situations entre hommes et femmes s'opère, mais parfois bien lentement. In: Regards sur la parité 2012, pp. 67-80. Paris: Insee. https://www.insee.fr/fr/statistiques/1372769?som maire $=1372781$

Amar, M. (2010). Les très hauts salaires du secteur privé. Insee Première $\mathrm{N}^{\circ} 1288$.

https://www.insee.fr/fr/statistiques/1281185

Blossfeld, H.-P. \& Buchholz, S. (2009). Increasing Resource Inequality among Families in Modern Societies: The Mechanisms of Growing Educational Homogamy, Changes in the Division of Work in the Family and the Decline of the Male Breadwinner Model. Journal of Comparative Family Studies, 40(4), 603-616.

Boiron, A., Huwer, M. \& Labarthe, J. (2016). Inégalités de niveaux de vie et pauvreté en 2013. In: Les revenus et le patrimoine des ménages 2016, pp. 9-21. Paris: Insee.

https://www.insee.fr/fr/statistiques/2017606?som maire $=2017614$

Bouchet-Valat, M. (2014). Les évolutions de l'homogamie de diplôme, de classe et d'origine sociales en France (1969-2011) : ouverture d'ensemble, repli des élites. Revue française de sociologie, 55(3), 459-505. / Changes in Educational, Social Class and Social Class of Origin Homogamy in France (1969-2011): Greater Openness Overall but Increased Closure of Elites. Revue française de sociologie, 55(3), 324-364.

Breen, R. \& Andersen, S. H. (2012). Educational Assortative Mating and Income Inequality in Denmark. Demography, 49(3), 867-887.

Breen, R. \& Salazar, L. (2010). Has Increased Women's Educational Attainment Led to Greater Earnings Inequality in the United Kingdom?
A Multivariate Decomposition Analysis. European Sociological Review, 26(2), 143-157.

Breen, R. \& Salazar, L. (2011). Educational Assortative Mating and Earnings Inequality in the United States. American Journal of Sociology, 117(3), 808-843.

Burtless, G. (1999). Effects of growing wage disparities and changing family composition on the U.S. income distribution. European Economic Review, 43(4-6), 853-865.

Cabannes, P.-Y. (2014). Trois décennies d'évolutions du marché du travail. In: Trente ans de vie économique et sociale, pp. 55-67. Paris: Insee. https://www.insee.fr/fr/statistiques/1374370?som maire $=1374377$

Cancian, M. \& Reed, D. (1998). Assessing the Effects of Wives' Earnings on Family Income Inequality. Review of Economics and Statistics, 80(1), 73-79.

Cancian, M. \& Reed, D. (1999). The impact of wives' earnings on income inequality: Issues and estimates. Demography, 36(2), 173-184.

Chardon, O., Daguet, F. \& Vivas, É. (2008). Les familles monoparentales : des difficultés à travailler et à se loger. Insee Première $\mathrm{N}^{\circ} 1195$. https://www.insee.fr/fr/statistiques/1281271

Charnoz, P., Coudin, É. \& Gaini, M. (2013). Une diminution des disparités salariales en France entre 1967 et 2009. In: Emploi et salaires 2013, pp. 75-86. Paris : Insee.

https://www.insee.fr/fr/statistiques/1374085?som maire $=1374092$

Courtioux, P. \& Lignon, V. (2015a). Homogamie éducative et inégalités de revenu salarial : une perspective de cycle de vie. Économie et Statistique, 481, 149-183.

https://www.insee.fr/fr/statistiques/1305199?som maire $=1305205$

Courtioux, P. \& Lignon, V. (2015b). L'effet de l'homogamie éducative sur les inégalités: une note méthodologique avec une illustration pour le cas français. Centre d'économie de la Sorbonne, Document de travail No 2015.91.

https://halshs.archives-ouvertes.fr/halshs-01254789/ 
Daly, M. C. \& Valletta, R. G. (2006). Inequality and Poverty in United States: The Effects of Rising Dispersion of Men's Earnings and Changing Family Behaviour. Economica, 73(289), 75-98.

Devereux, P. J. (2004). Changes in relative wages and family labor supply. Journal of Human Resources, 39(3), 698-722.

Eika, L., Mogstad, M. \& Zafar, B. (2014). Educational assortative mating and household income inequality. Federal Reserve Bank of New York, Staff Report 682.

http://www.nber.org/papers/w20271

Esping-Andersen, G. (2007). Sociological Explanations of Changing Income Distributions. American Behavioral Scientist, 50(5), 639-658.

Frémeaux, N. (2014). Le rôle de l'héritage et du revenu du travail dans les choix matrimoniaux. Population, 69(4), 551-587.

Frémeaux, N. \& Lefranc, A. (2015). Assortative mating and earnings inequality in France. Université de Cergy-Pontoise - THEMA, Mimeo. http://www.ecineq.org/ecineq_lux15/FILESx2015/ CR2/p224.pdf

Funes Leal, V. (2015). Efectos del Emparejamiento Selectivo en la Distribución del Ingreso en América Latina. Universidad Nacional de La Plata, Thesis de Maestría en Economía.

http://www.depeco.econo.unlp.edu.ar/maestria/ tesis/117-tesis-Funes-Leal.pdf

Godechot, O. (2012). Is finance responsible for the rise in wage inequality in France? SocioEconomic Review, 10(3), 447-470.

Godechot, O. (2013). Financiarisation et fractures socio-spatiales. L'Année sociologique, 63(1), 17-50. / [2014] Financialization and Sociospatial Divides

Greenwood, J., Guner, N., Kocharkov, G. \& Santos, C. (2014). Corrigendum to Marry Your Like: Assortative Mating and Income Inequality. American Economic Review: Papers \& Proceedings, 104(5), 1-2.

Harkness, S. (2013). Women's Employment and Household Inequality. In: J. Gornick \& M. Jäntti (Ed.), Income Inequality: Economic Disparities and the Middle Class in Affluent Countries (p. 207-233). Stanford: Stanford University Press.
Hryshko, D., Juhn, C. \& McCue, K. (2014). Trends in Earnings Inequality and Earnings Instability among US Couples: How Important Is Assortative Matching? Forschungsinstitut zur Zukunft der Arbeit (IZA), Discussion Paper 8729. http://papers.ssrn.com/sol3/papers.cfm?abstract _id $=2543924$

Hyslop, D. R. (2001). Rising U.S. Earnings Inequality and Family Labor Supply: The Covariance Structure of Intrafamily Earnings. The American Economic Review, 91(4), 755-777.

Insee (2016). Marché du travail - Séries longues. Insee Résultats $\mathrm{N}^{\circ} 175$.

https://www.insee.fr/fr/statistiques/1406870

Karoly, L. A. \& Burtless, G. (1995). Demographic change, rising earnings inequality, and the distribution of personal well-being, 1959-1989. Demography, 32(3), 379-405.

Landais, C. (2007). Les hauts revenus en France (1998-2006) : une explosion des inégalités? École d'économie de Paris, Document de travail. / [2008] Top Incomes in France: booming inequalities? Paris School of Economics, Working paper.

http://piketty.pse.ens.fr/fichiers/Landais2007.pdf

Larrimore, J. (2014). Accounting for United States Household Income Inequality Trends: The Changing Importance of Household Structure and Male and Female Labor Earnings Inequality. Review of Income and Wealth, 60(4), 683-701.

Meron, M. (2008). Femmes et hommes dans l'emploi : permanences et évolutions. In: L'emploi, nouveaux enjeux (Édition 2008), pp. 85-93. Paris: Insee.

https://www.insee.fr/fr/statistiques/1374398? sommaire $=1374407$

Meron, M. \& Maruani, M. (2012). Un siècle de travail des femmes en France. 1901-2011. Paris: La Découverte.

Minni, C. (2015). Femmes et hommes sur le marché du travail : les disparités se réduisent mais les emplois occupés restent très différents. Dares analyses $\mathrm{N}^{\circ} 17$.

travail-emploi.gouv.fr/IMG/pdf/2015-017.pdf

Morin, T. (2014). Écarts de revenus au sein des couples : Trois femmes sur quatre gagnent moins que leur conjoint. Insee Première $\mathrm{N}^{\circ} 1492$. https://www.insee.fr/fr/statistiques/1281400 
OCDE (2008). Croissance et inégalités : Distribution des revenus et pauvreté dans les pays de l'OCDE. Paris: Organisation de coopération et de développement économiques. / OECD. Growing Unequal: Income Distribution and Poverty in OECD Countries.

OCDE (2011). Toujours plus d'inégalité : Pourquoi les écarts de revenus se creusent. / OECD. Divided We Stand: Why Inequality Keeps Rising. Paris: Organisation de coopération et de développement économiques.

O'Prey, S. (2009). La non-réponse partielle aux variables financières de l'enquête Logement 2006 : mise en œuvre de nouvelles procédures de redressement et comparaison de méthodes d'imputation. Insee, Document de travail F0901.

http://www.insee.fr/fr/publications-et-services/ docs_doc_travail/F0901.pdf

Pasqua, S. (2002). Wives' work and income distribution in European countries. The European Journal of Comparative Economics, 5(2), 197-226.

Pencavel, J. (2006). A life cycle perspective on changes in earnings inequality among married men and women. The Review of Economics and Statistics, 88(2), 232-242.

Piketty, T. (2013). Le capital au XXI siècle. Paris: Seuil. / [2014] Capital in the Twenty-First Century. Cambridge: Harvard University Press.

Pujol, J. \& Tomasini, M. (2009). Les inégalités de niveaux de vie entre 1996 et 2007. Insee Première $\mathrm{N}^{\circ} 1266$.

https://www.insee.fr/fr/statistiques/1286908

Ravel, C. (2007). La polarisation de l'emploi au sein des ménages de 1975 à 2002. Économie et statistique, 402(1), 3-23.

https://www.insee.fr/fr/statistiques/1376852? sommaire $=1376860$

Reed, D. \& Cancian, M. (2001). Sources of inequality: measuring the contributions of income sources to rising family income inequality. Review of Income and Wealth, 47(3), 321-333.
Reed, D. \& Cancian, M. (2012). Rising Family Income Inequality: The Importance of Sorting. Journal of Income Distribution, 21(2), 3-14.

Schwartz, C. R. (2010). Earnings Inequality and the Changing Association between Spouses' Earnings. American Journal of Sociology, 115(5), 1524-1557.

Solard, J. (2010). Les très hauts revenus : des différences de plus en plus marquées entre 2004 et 2007. In: Les revenus et le patrimoine des ménages 2010, pp. 45-64. Paris: Insee.

https://www.insee.fr/fr/statistiques/1373531?som maire $=1373536$

Vanderschelden, M. (2006). Homogamie socioprofessionnelle et ressemblance en termes de niveau d'études : constat et évolution au fil des cohortes d'unions. Économie et statistique, 398-399, 33-58.

https://www.insee.fr/fr/statistiques/1376345?som maire $=1376355$

Verbakel, E. (2008). The Partner as Resource or Restriction? Labour market careers of husbands and wives and the consequences for inequality between couples. Radboud University, Nijmegen.

Verdugo, G. (2014). The great compression of the French wage structure, 1969-2008. Labour Economics, 28(4), 131-144.

Verdugo, G., Fraisse, H. \& Horny, G. (2012). Évolution des inégalités salariales en France : le rôle des effets de composition. Revue économique, 63(6), 1081-1112.

Western, B., Bloome, D. \& Percheski, C. (2008). Inequality among American families with children, 1975 to 2005. American Sociological Review, 73(6), 903-920.

Worner, S. M. (2006). The Effects of Assortative Mating on Income Inequality: A Decompositional Analysis. Centre for Economic Policy Research - Australian National University, Discussion Paper 538.

https://ideas.repec.org/p/auu/dpaper/538.html 
FIT STATISTICS FOR THE MODELS USED FOR THE DECOMPOSITION

\begin{tabular}{|l|c|c|c|c|c|}
\hline & D. F. & Deviance & $\Delta(\%)^{(2)}$ & BIC $^{(3)}$ & $\mathrm{AlC}^{(4)}$ \\
\hline M1 : Full independence & 14,480 & 57,114 & 19.86 & $-120,844$ & 28,154 \\
M2 : M1 + Employment rate of women & 13,840 & 49,073 & 17.57 & $-121,019$ & 21,393 \\
M3 : M2 + Employment rate of men & 13,200 & 46,593 & 17.08 & $-115,634$ & 20,193 \\
M4 : M3 + Stable employment-wage association & 13,180 & 40,948 & 14.56 & $-121,033$ \\
M5 : M4 + Full stable association & 12,800 & 16,091 & 9.51 & $-141,219$ & $-9,509$ \\
M6 : M5 + Varying employment-wage association & 12,780 & 15,886 & 9.33 & $-141,179$ & $-9,674$ \\
\hline
\end{tabular}

(1) Degrees of freedom. (2) Index of dissimilarity. ${ }^{(3)}$ Bayesian Information Criterion. ${ }^{(4)}$ Akaike Information Criterion. These last two indicators measure the quality of the description of the data performed by each model taking into account their parsimony (number of parameters to be estimated): a lower value (or a more negative one) indicates a statistically significant improvement compared to a model displaying a higher value.

Note: $\mathrm{N}=217,489$. Number of cells in the table: 14,553 .

Coverage: men and women cohabiting, where the partners are aged between 30 and 59 and neither is self-employed or retired. Source: Insee, Labour Force Surveys (enquêtes Emploi), 1982-2014. 
